\title{
Congenital nasal pyriform aperture stenosis: a rare condition treated successfully by expectant management
}

\author{
Wrodzone zwężenie otworu gruszkowatego nosa: rzadki przypadek leczony z powodzeniem \\ metodą postępowania wyczekującego \\ 1 Department of Ear, Nose, Throat and Head \& Neck Surgery, School of Medical Sciences, Universiti Sains Malaysia, Kota Bharu, Malaysia \\ ${ }^{2}$ Department of Radiology and Diagnostic Imaging, School of Medical Sciences, Universiti Sains Malaysia, Kota Bharu, Malaysia \\ Correspondence: Dr. Madhusudhan Krishnamoorthy (MBBS), Department of Ear, Nose, Throat and Head \&Neck Surgery, School of Medical Sciences, Universiti Sains Malaysia, 16150 Kubang Kerian, Kota Bharu, \\ Kelantan, Malaysia, e-mail: kmadhu_87@yahoo.com, ORCID ID: https://orcid.org/0000-0001-6105-2881
}

\begin{abstract}
Aim: Our aim is to highlight the successful treatment of congenital nasal pyriform aperture stenosis by expectant management and the importance to understand other disorders that may occur alongside it. Discussion: Congenital nasal pyriform aperture stenosis may occur in isolation, or as a part of the holoprosencephaly spectrum. This case report demonstrates the role of diagnostic imaging to confirm its diagnosis and to look for other concurrently occurring pathologies. Case history: We report a newborn developing respiratory embarrassment shortly after birth, requiring intubation to sustain breathing. A diagnosis of congenital nasal pyriform aperture stenosis was clinched as evidenced by the radioimaging features. The patient also had a solitary median maxillary central incisor. Conclusion: Expectant management has proved to be beneficial as exemplified in this case report. Although this rare disease may present as an isolated entity, it is paramount to be mindful of other anomalies that may coexist.
\end{abstract}

Keywords: incisor, neonate, holoprosencephaly, stenosis

Streszczenie Cel pracy: Celem autorów było podkreślenie skuteczności leczenia wrodzonego zwężenia otworu gruszkowatego nosa metodą postępowania wyczekującego oraz uwypuklenie roli innych zaburzeń, które mogą współistnieć z omawianą jednostką chorobową. Omówienie: Wrodzone zwężenie otworu gruszkowatego nosa może występować jako anomalia izolowana lub jako element spektrum zaburzeń holoprozencefalii. Przedstawiony opis przypadku ukazuje rolę diagnostyki obrazowej w potwierdzeniu rozpoznania oraz ujawnieniu ewentualnych innych współistniejących patologii. Opis przypadku: Autorzy przedstawiają przypadek noworodka, u którego krótko po urodzeniu stwierdzono zaburzenia oddychania wymagające intubacji w celu podtrzymania oddechu. Rozpoznanie wrodzonego zwężenia otworu gruszkowatego nosa ustalono na podstawie cech w badaniu radioobrazowym. U pacjenta odnotowano także pojedynczy środkowy siekacz szczęki. Wniosek: Niniejszy opis przypadku dowodzi, że postępowanie wyczekujące jest skuteczną metodą. Chociaż ta rzadka jednostka chorobowa może występować jako zaburzenie izolowane, należy mieć na uwadze możliwość współistnienia innych anomalii.

Słowa kluczowe: siekacz, noworodek, holoprozencefalia, zwężenie 


\section{INTRODUCTION}

$\mathrm{N}$ asal pyriform aperture stenosis was first described by Douglas in $1952^{(1)}$. However, it was not until 1989 that congenital nasal pyriform aperture stenosis (CNPAS) was first reported. In their landmark case series, Brown et al. successfully described CNPAS as an unusual cause of nasal airway obstruction in newborns, and further described the needful management recommendations ${ }^{(2)}$. Subsequently in a 1992 case series by Arlis and Ward, an additional feature of "megaincisor" involving CNPAS patients was reported. They proposed that CNPAS may in fact be a midfacial dysostosis with associated endocrine and central nervous system anomalies ${ }^{(3)}$. The purpose of this report is to highlight the successful treatment of CNPAS in an expectant manner and the importance to understand other pathologies that may occur simultaneously with CNPAS.

\section{CASE REPORT}

Our patient was a $3.8 \mathrm{~kg}$ male delivered post-term at 42 -weeks gestation by a 23 -year-old gravida 2 para 1 female. His mother had gestational diabetes mellitus, requiring insulin for sugar control. Otherwise, the pregnancy was uncomplicated and there was no history of maternal exposure to teratogens. The delivery was by emergency lower segment Caesarean section as the foetal cardiotocography was highly suspicious of foetal distress with an anticipated macrosomic baby. Apgar score was 9 at 1 minute and the child had a good loud cry. The child was noted to have severe subcostal retractions with hyperinflated chest at 5 hours of life and was transferred to the neonatal intensive care unit for close observation. The condition of the child gradually worsened, as he was unable to sustain spontaneous breathing and developed

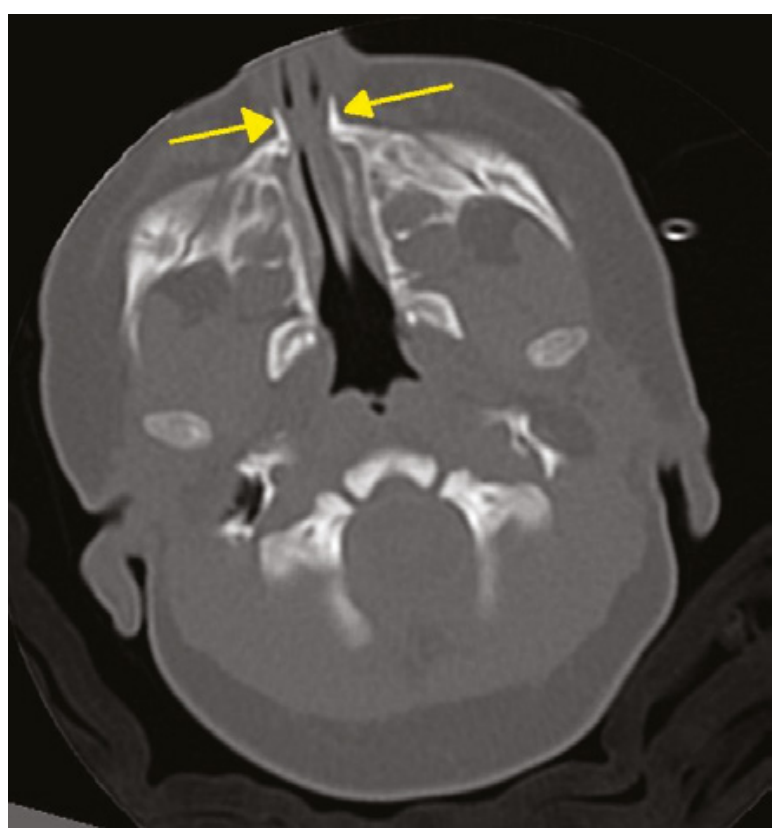

Fig. 1. Narrowed pyriform aperture

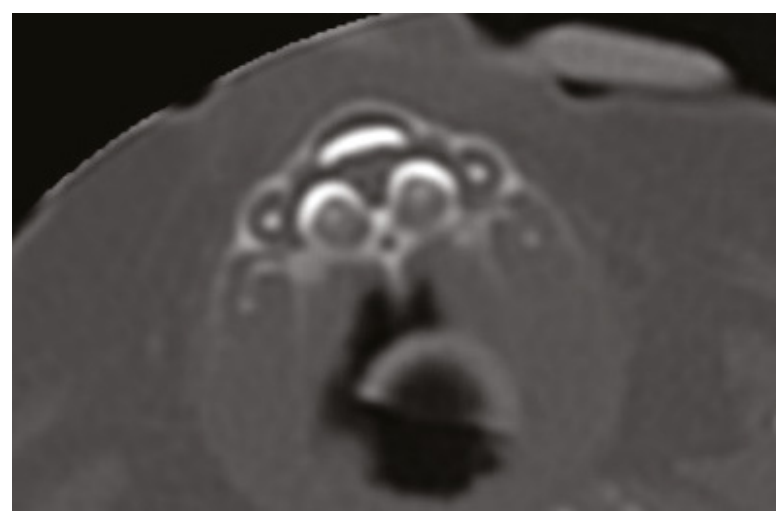

Fig. 2. Single median maxillary central incisor

cyclical cyanosis relieved by crying. He was subsequently intubated at 48 hours of life in view of respiratory distress. As there was an immense difficulty to insert a size 5French (Fr) flexible suction catheter via the nostril, an urgent ear, nose and throat (ENT) consult was sought for. The ENT examination was unremarkable; however, the flexible fiberoptic scope could only be inserted into the nasal vestibule, but not beyond the bony valve area. An urgent computed tomography scan revealed CNPAS (Fig. 1). There was also a single unerupted deciduous median maxillary central incisor (Fig. 2). The child was subsequently extubated 4 days later and was keeping well with a McGovern nipple to secure his airway and an orogastric feeding tube in place (Fig. 3). The patient was discharged home in a good condition at day 20 of life, after almost 3 weeks of hospitalisation. During his follow up at 1 month of age, the infant was doing well, with neither any difficulty to breath nor any difficulty in feeding (Fig. 4).

\section{DISCUSSION}

Although nasal pyriform aperture stenosis was first described almost seven decades ago ${ }^{(1)}$, it was not until 1989 that the first case series on CNPAS was published ${ }^{(2)}$. CNPAS has been reported to be an infrequent cause of nasal airway obstruction in infants and neonates, however the true incidence rate is still unknown ${ }^{(4)}$. To the best of our knowledge, there have been only 2 cases of CNPAS reported in Malaysia till date. Congenital nasal airway obstruction occurs in up to 1 in 5,000 newborns most of which are due to choanal atresia ${ }^{(5)}$. It is believed that CNPAS occurs at a frequency about onefifth $(1 \text { in } 25,000)^{(6,7)}$ to one-third that of choanal atresia. Before understanding the development of CNPAS, the pertinent anatomy of the pyriform aperture must be studied. The aperture is named likewise due to its pear-shaped outline. It is the most anterior and narrowest opening of the bony nasal airway ${ }^{(2,7,8)}$. Its superior and inferior limits are the nasal bones and the junctions of palatine processes of maxillae with anterior nasal spine on either sides respectively. Laterally, it is bounded by the nasal processes of either maxillae, and medially it is bounded by the nasal septum ${ }^{(7,9)}$. Since infants are obligate nasal breathers, small changes in 


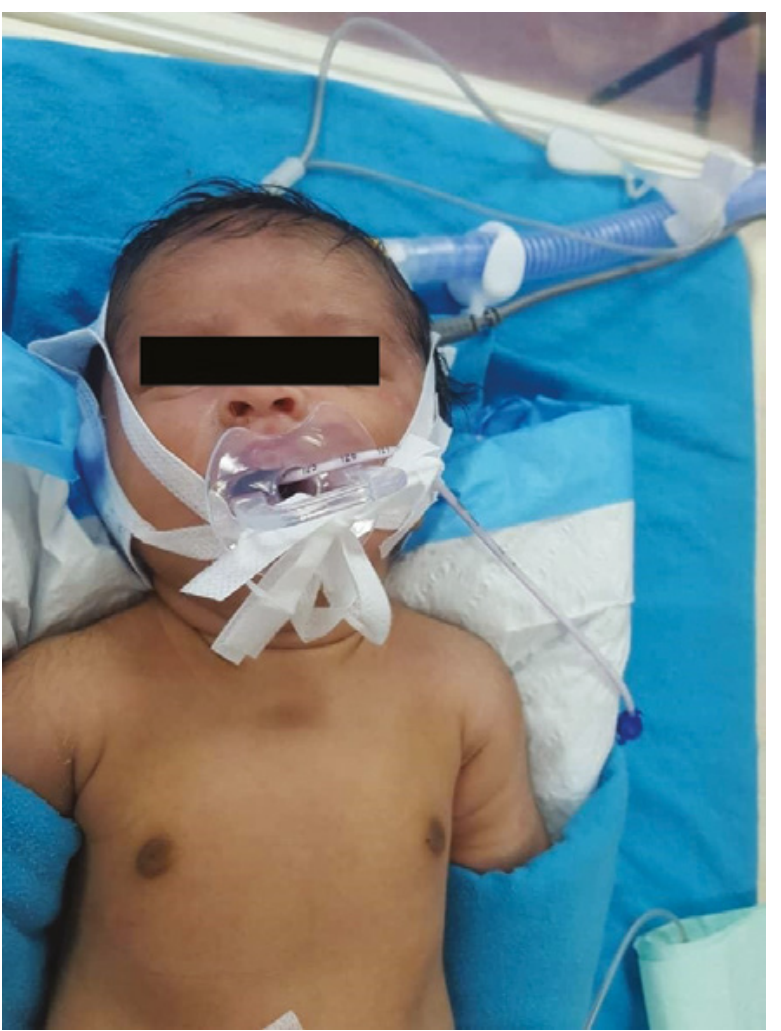

Fig. 3. Patient with McGovern nipple in place

the cross-sectional area of the pyriform aperture dimension, can result in a dramatic increase in nasal airway resistance. As a result of this, the typical symptoms and signs of CNPAS ensue. The classical symptoms are cyclical cyanosis, apneic episodes and feeding difficulties ${ }^{(2,10)}$. Clinical suspicion is also based on the difficulty to insert a nasogastric tube size 5French. The basis of development of CNPAS is due to bony overgrowth. The primitive nose develops at 5-8 weeks of gestation. During this period, the developing maxillae meet the lateral nasal process to form the pyriform aperture and the lateral nasal wall ${ }^{(8)}$. It is proposed that an overgrowth of maxillary ossification at the nasal process is accountable for the bony stenosis seen in CNPAS ${ }^{(2,11)}$. Although CNPAS is a developmental anomaly of the nose, it is considered as a holoprosencephaly variant ${ }^{(4)}$. Holoprosencephaly is regarded as a developmental defect which often occurs sporadically ${ }^{(9,12)}$. There have also been reports of familial holoprosencephaly transmitted in both autosomal recessive as well as autosomal dominant (with incomplete penetrance) patterns ${ }^{(12,13)}$. Simply put, a developmental field is a part of the embryo where complex structures develop in a spatially ordered, coordinated and timely organised fashion ${ }^{(3)}$. The embryologic basis of development of holoprosencephaly is due to the defective midline facial development by the midline facial prechordal mesoderm. The deprivation of the midline facial prechordal mesoderm to induce differentiation of neural ectoderm leads to the inability of the prosencephalon to di$\operatorname{vide}^{(3,13)}$. As such, cerebral defects of holoprosencephaly may range from the alobar type (brain fails to divide into two

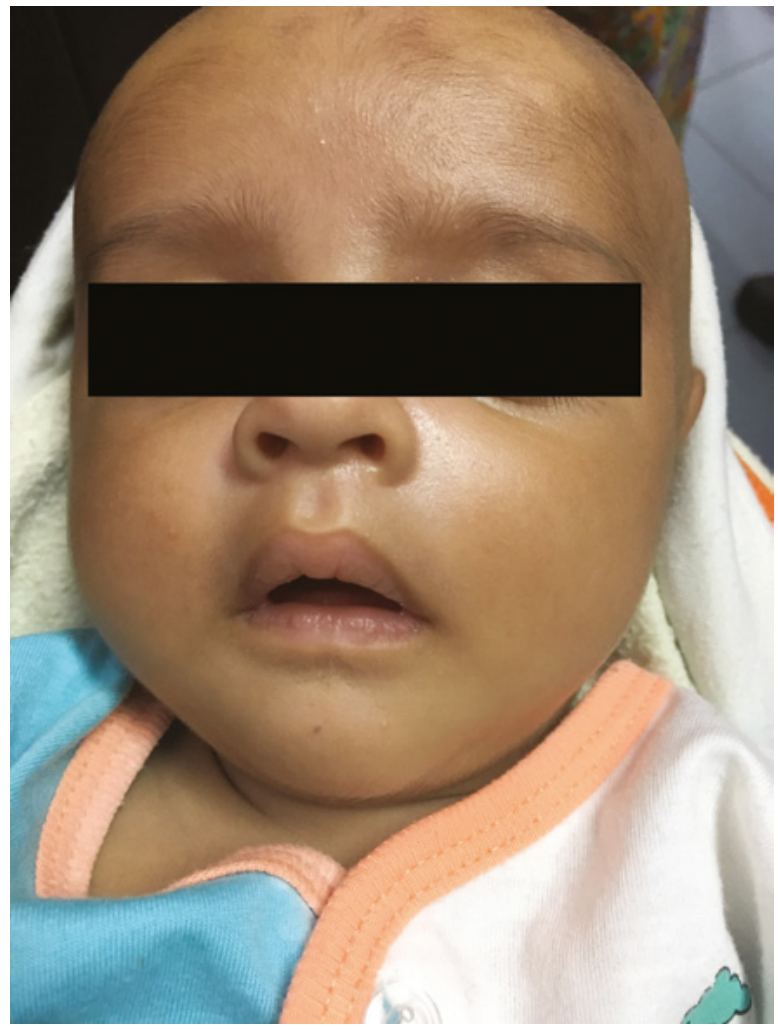

Fig. 4. Patient seen in clinic keeping well at 1 month of life

hemispheres) to lobar type (small well-formed hemispheres with absence of corpus callosum and absence of olfactory bulb $)^{(11,13)}$. There may be concurrent midline facial anomalies seen in holoprosencephaly ranging from the mildest form, such as a single median maxillary central incisor (SMMCI) ("megaincisor") as seen in our case report. This mildest form has been reported as the autosomal dominant microform of holoprosencephaly ${ }^{(9)}$. The other end of the spectrum would be the most extreme form which is cyclopia ${ }^{(3,10)}$. Numerous case series have shown that anywhere between 14-66\% of children with CNPAS were found to have $\mathrm{SMMCI}^{(5)}$. As the midline facial framework is involved, there are other various anomalies worth mentioning in the continuum of the spectrum, such as ethmocephaly, cebocephaly, midline cleft palate, hypotelorism and a flat nose ${ }^{(13)}$. Various aetiologies for holoprosencephaly have been documented, however most cases are idiopathic ${ }^{(13)}$. Chromosomal abnormalities associated with holoprosencephaly are trisomy 13, ring chromosome 18 and deletion of long arm of chromosome $18^{(13)}$. Teratogenic effects documented include maternal diabetes and maternal alcohol consumption ${ }^{(11)}$. This was clearly evident in our case report. The endocrine system of the newborn may also be affected, such as a case of absent pituitary gland, as well as another case of growth hormone deficiency ${ }^{(10,13)}$. In fact, the incidence of pituitary dysfunction has been reported to be as high as $15-22.5 \%{ }^{(5)}$. To aid the diagnosis of CNPAS, the gold standard diagnostic tool would be computed tomography (CT) $\operatorname{scan}^{(2,5)}$. However, prior to performing the scan, a few common differential 


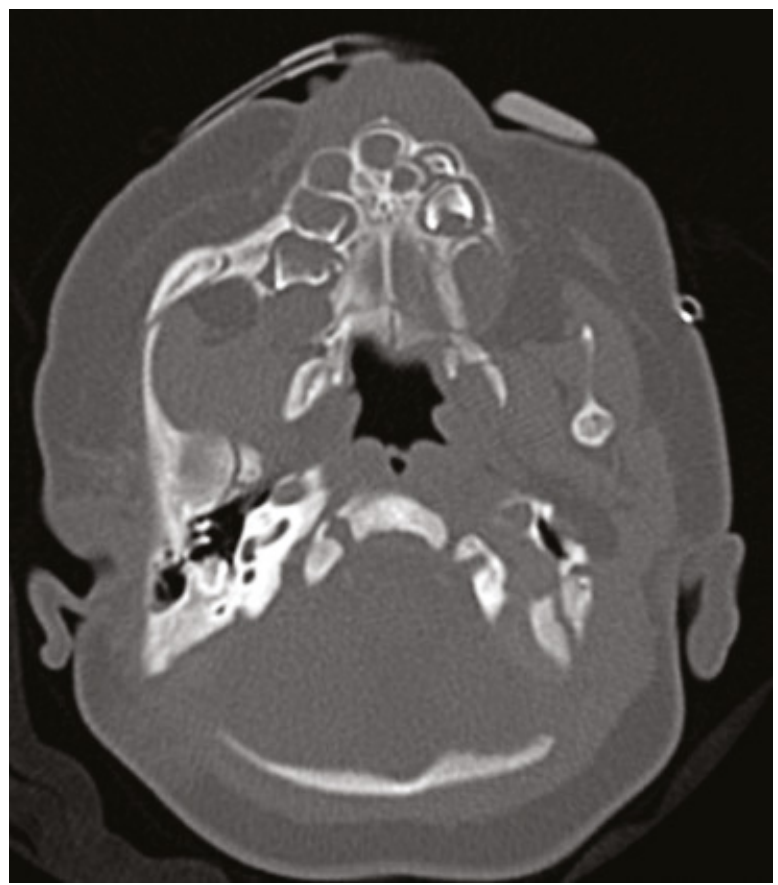

Fig. 5. Triangular shaped palate with a midline ridge

diagnoses with similar symptoms should be considered, namely: i) bilateral choanal atresia, ii) teratoma, iii) congenital nasal tumours, and iv) dacryocystocele $e^{(4,5,8)}$. The most common amongst them is choanal atresia, which is easily differentiated by the level of obstruction which is more posterior (approximately $3 \mathrm{~cm}$ ) and the ability to insert a suction catheter up to a size $8 \mathrm{Fr}$. On the contrary, the level of obstruction in CNPAS is more anterior (approximately $1 \mathrm{~cm}$ ) and there will be difficulty to insert a suction catheter size $5 \mathrm{Fr}^{(4,5)}$. The CT scan should be read with linear measurements taken parallel to the Frankfurt plane at the level of the inferior meatus ${ }^{(5,7)}$. The appropriate axial cuts thickness suggested are 1-3 mm. The measurement taken for diagnosis is the distance between the medial sides of bilateral nasal processes of maxillae, the inter-process distance (IPD) ${ }^{(10)}$. Various authors have defined CNPAS based on different values. Chinwuba et al. suggested that a nasal airway diameter of $<2 \mathrm{~mm}$ is diagnostic of CNPAS in preterm babies, while Osovsky et al. reported an IPD of $<8 \mathrm{~mm}$ as $\operatorname{diagnostic}^{(\text {acc. to 10) }}$. For the ease of reporting and diagnostic purposes, we suggest to use the widely accepted diagnostic value reported by Belden et al. which is an IPD of $<11 \mathrm{~mm}^{(6)}$. After performing a CT scan, specific features which may be present in CNPAS like SMMCI, triangular palate and palatal bony ridges need to be looked for ${ }^{(14)}$. Our case report had all of the 3 features above (Fig. 5). Once the diagnosis is confirmed and other pathologies ruled out, treatment would be tailor made according to the patient. The treatment can be generally divided into surgical treatment and expectant treatment. Generally, surgical intervention is warranted when expectant management fails, or when a patient does not respond to medical treatment after 15 days ${ }^{(4,5)}$.
The commonest surgical method worth mentioning is the sublabial approach (maxillary vestibule) to remove the bony stenosis $^{(2)}$. The other method of expanding the pyriform aperture stenosis is of historical significance which is the transnasal approach ${ }^{(2)}$. It is more challenging due to the small dimensions of an infant's nose. Lately however, there have been literature reports of lesser invasive procedures like dilatation, either using a Hegar's cervical dilator or a balloon dilatation technique ${ }^{(4,14)}$. As the commonly performed surgical procedure is the sublabial approach to widen the pyriform aperture, risks such as injury to un-erupted teeth buds, injury to nasolacrimal ducts as well as restenosis have been reported ${ }^{(4)}$. In fact, a systematic review published in 2015 by Gonik et al. showed a $14 \%$ treatment failure rate in patients undergoing surgery for CNPAS ${ }^{(15)}$. Therefore, it is wise to consider expectant management in a newly diagnosed CNPAS patient prior to performing surgery. The clinical presentation of the patient rather than a narrowed IPD should be an indication for surgery ${ }^{(10)}$. As seen in our case report, we successfully managed the patient with a McGovern's nipple post extubation and topical nasal decongestion application ${ }^{(3,8)}$. As the patient grows, the IPD widens and symptoms will eventually resolve. Infants will gradually outgrow the disorder and start oral breathing, anywhere between 3 and 6 months of age ${ }^{(4,5)}$. Hui et al. highlighted successful outcomes in patients managed non-surgically ${ }^{(11)}$. Once the acute airway issues have been treated, the child can be screened for endocrine anomalies to ensure an intact hypothalamic-pituitary-thyroidadrenal axis as well as a chromosomal analysis study to rule out genetic anomalies $^{(8)}$. Should there be a high suspicion of any intracranial pathology, magnetic resonance imaging of the brain should be done to detect any subtle midline dysgenesis or pituitary gland anomalies ${ }^{(9)}$.

\section{CONCLUSION}

CNPAS is a rare disease affecting neonates and infants, which may be associated with various other anomalies. Prior to arriving at the final diagnosis, various differentials must be borne in mind. With the aid of a CT scan, the final diagnosis can be clinched, and other features have to be looked for specifically. It is crucial to note that CNPAS may occur simultaneously with other pathologies of the endocrine and central nervous system. The treating physician should be aware of such conditions and not focus on the airway alone.

\section{Conflict of interest}

The authors do not report any financial or personal connections with other persons or organizations, which might negatively affect the content of this publication and/or claim authorship rights to this publication.

\section{Acknowledgements}

The authors would like to thank Professor Suzina and Professor Noraida for their clinical acumen and guidance in managing this case, without whom this case report would not have been possible. 


\section{References}

1. Douglas B: The relief of vestibular nasal obstruction by partial resection of the nasal process of the superior maxilla. Plast Reconstruct Surg (1946) 1952; 9: 42-51.

2. Brown OE, Myer CM $3^{\text {rd }}$, Manning SC: Congenital nasal pyriform aperture stenosis. Laryngoscope 1989; 99: 86-91.

3. Arlis H, Ward RF: Congenital nasal pyriform aperture stenosis. Isolated abnormality vs developmental field defect. Arch Otolaryngol Head Neck Surg 1992; 118: 989-991.

4. Castaño JE, Chi DH: Pyriform aperture stenosis repair in infants. Oper Tech Otolaryngol Head Neck Surg 2018; 29: 51-54.

5. Moreddu E, Le Treut-Gay C, Triglia JM et al.: Congenital nasal pyriform aperture stenosis: elaboration of a management algorithm from 25 years of experience. Int J Pediatr Otorhinolaryngol 2016; 83: 7-11.

6. Belden CJ, Mancuso AA, Schmalfuss IM: CT features of congenital nasal piriform aperture stenosis: initial experience. Radiology 1999; 213: 495-501.

7. Wormald R, Hinton-Bayre A, Bumbak P et al.: Congenital nasal pyriform aperture stenosis $5.7 \mathrm{~mm}$ or less is associated with surgical intervention: a pooled case series. Int J Pediatr Otorhinolaryngol 2015; 79: 1802-1805.
8. Lee JJ, Bent JP, Ward RF: Congenital nasal pyriform aperture stenosis: non-surgical management and long-term analysis. Int J Pediatr Otorhinolaryngol 2001; 60: 167-171.

9. Huang JK, Cheng SJ, Lin JCT et al.: Congenital nasal pyriform aperture stenosis and single central maxillary incisor: CT and MRI findings. Clin Imaging 1998; 22: 393-397.

10. Lin KL, Lee KS, Yang CC et al.: The natural course of congenital nasal pyriform aperture stenosis. Laryngoscope 2016; 126: 2399-2402.

11. Hui Y, Friedberg J, Crysdale WS: Congenital nasal pyriform aperture stenosis as a presenting feature of holoprosencephaly. Int J Pediatr Otorhinolaryngol 1995; 31: 263-274.

12. Johnson VP: Holoprosencephaly: a developmental field defect. Am J Med Genet 1989; 34: 258-264.

13. Tavin E, Stecker E, Marion R: Nasal pyriform aperture stenosis and the holoprosencephaly spectrum. Int J Pediatr Otorhinolaryngol 1994; 28: 199-204.

14. Gungor AA, Reiersen DA: Balloon dilatation for congenital nasal piriform aperture stenosis (CNPAS): a novel conservative technique. Am J Otolaryngol 2014; 35: 439-442.

15. Gonik NJ, Cheng J, Lesser $M$ et al.: Patient selection in congenital pyriform aperture stenosis repair - 14 year experience and systematic review of literature. Int J Pediatr Otorhinolaryngol 2015; 79: 235-239. 